University of Louisville

ThinkIR: The University of Louisville's Institutional Repository

Electronic Theses and Dissertations

$1-1928$

\title{
The preparation of hydroxy-acridines and different 5-position acridine derivatives.
}

Francis Bratten Rethwisch

University of Louisville

Follow this and additional works at: https://ir.library.louisville.edu/etd

\section{Recommended Citation}

Rethwisch, Francis Bratten, "The preparation of hydroxy-acridines and different 5-position acridine derivatives." (1928). Electronic Theses and Dissertations. Paper 1198.

https://doi.org/10.18297/etd/1198

This Master's Thesis is brought to you for free and open access by ThinkIR: The University of Louisville's Institutional Repository. It has been accepted for inclusion in Electronic Theses and Dissertations by an authorized administrator of ThinkIR: The University of Louisville's Institutional Repository. This title appears here courtesy of the author, who has retained all other copyrights. For more information, please contact thinkir@louisville.edu. 
Gndvosasty of sousev1320

Tho Properstion of DVArosy-Aostdinoo

and Drforent 5mpostson

Aoridino Dorivativos

A Bscortatson

suthat thed to the roculty

of the

Graduete sohool of Rbarel Arts

In Partial Dulctimont

of tise

Rogulsements

Sor the socroo

of

raster of solence

Dopartmont of Chondstry

DV

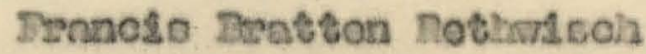

2928 


\section{THE PREPARASIOH OF EXDROXY-ACREDTES}

\section{AID DIBEEREIT 6-POSIXIOI}

ACRIDIUE DERIVATIVIS

\section{Introduction}

Jonson and Friedrich $\mathrm{ch}^{2}$ have outsined nor methode for tho proparstion of aerialne compounds. Whey have shown that the troatment of omentnobenseldohyde with tho helogion dorivatives of nitrobensono and with the corroeponding corivativon of toluono would yiold the corrosponaing diphonylemino derivetivee. These Aiphonylemine derivativos split off mater very oosily to form sortdine compounds. Dy this mothod they have proparod the $3(9)-n i$ tro and $3(7)-n i t r o s e r i d i n e$, and tho $L(9)$-mothy 1 and $3(7)$-tiotivieoridine.

Tho genoral applicetion of the reaotion usod in proparing those compounde hes beon crantnod, and $2 t$ heg boon found tast the roection cen be cxtondod in two weys. Helogen dorivatuvos of bensono compounde, othor then those mentioned, cen bo weod, or the oninobonzeldohyde con be ropleeed by oucmino phonylIsetones.

The helogen derizetives of phenole were chooon

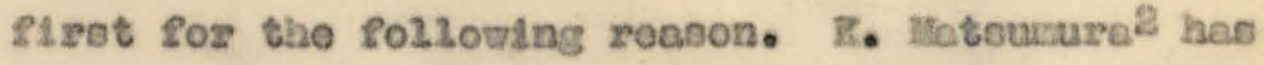


doecribod the properation of $2(\theta)$-hydroxyeoridine by roduotion of tho corrosponding ecrldone compound in bolisng anyl elcohol wh th soditur. Theso reoulte aocmod open to guestion becenes it tres belloved thet the ditydrocoridino shouzd be obtained, sinoo aorie dino 1 tsols whll givo dihydroaeridino under tho oble altione stated. Ao the produets obieinod from the phonol are Identicel with those of the Jopenese cheme 10t, no hydrogenetion of the cerldine ring occurred during tho reduetion. In this work the froo phonole coukd not bo ueed as the hudroxy group 2 tsels reectod. For this roeson the mothyl and othyl ethers were ouployed.

Boxt the o-aminobonzeldenydio was ropleced by Geamdnophory kkotones. This reaction shoukd boed to Grposition soridino dorivotivos eccoralng to tho following acheno:

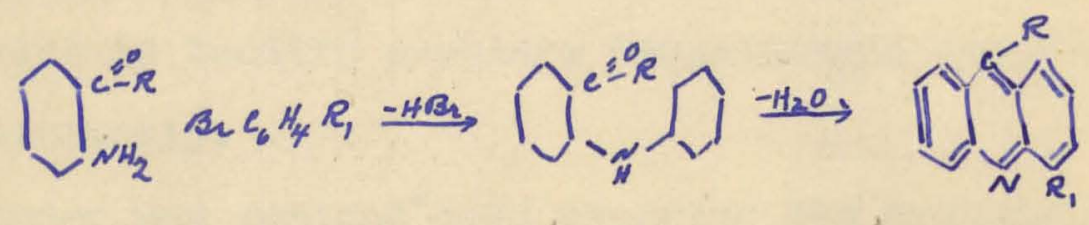

For I the investigetions included the lydrogen, methyl, and phonyl sroups, and for $R_{2}$ the metingl, ndtro, and alkory groups, which wore in olther ortho or pare postion to the halogen. In all coeos 16 wos poealble to secure the corrosponding borldino compoundo without groot diefsousty. 
5. Iraver ${ }^{3}$ has ohoun that tho ohzorino in oachloroeotophonone do not labito enowgh to resot with aroEntio andno compounds to glvo tho corrosponding die phonylenino dorivetives es is the cese with occhlorobonsophenone. It was thought thet by antroducing $\mathrm{e}$ nato group in the pore posation to tho hologon, that the latter could bo thade noro reective. It was found thet the chlerine in 5ent tro 2-chloro cootophonone rescte vory rosaliy whth andune to givo tho corresponding diphenylemine derivetive. Tho latter could be convorted vory cesily $1 \mathrm{n} 60$ s(7)-nstro 5-botingi dorldine, whioh hes olso been prepored in e asferent way. Exporinonte indeate that the chiorino in S-nitro bechloro seotophonone reacts also vith Oo and De nitroaniline. These produets vould elvo dinitro nothylecrldines in the finel stop of the reo cotione. It would bo snterosting to soe if the chlorkne in Denstro a-chloro benealdolyde voukd rosot asmilarky.

Jonson and Howlend heve roported the synthosts of acridsno-5eothylemine. This compound hos boon teotod for 1 to antisoptic properties, and thece jroIIminary exporlmonte Indeate that the compound

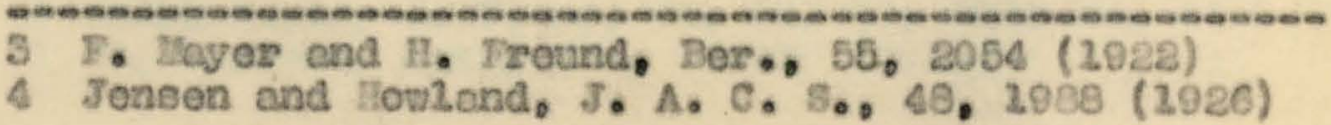


possoesos entieeptie properties which malie $1 \mathrm{t}$ worth whate to prepere oorpounde osmiler to this one. Dirst it wse thought worth while to propere lower honologued of cerdasno othylemine-that is, Geanino and 5amotinyzanino ecridine. It weo intendod to prepere the 5-amino ceridine by convorting the ester of seridine-beerborylio aold by the reection of Curtius into 5-oulno eoridine. The proparetion of the mothyl end ethyl estors of the ecridine-5-carborylie acid may be reported. The soridine-5-cerbosylie actd coukd not bo eotorifiod with alcohol and bydrochloric aold, nelthor by letting the miaturo stand in tho cold for aovorel days, nor by hoating for two deys. Wo zoection coukd be obtedned with sulfurle acid and eld cohol. Pratesnger ${ }^{5}$ observed the extie phenomonon in tho canes of the $\beta$ abothyl- and of tho $\beta$-phonylo cla ohonte actds, as did aseo Borscho ${ }^{6}$ in the caso of totrahydroeeridine- -oearboxy 120 acid. Steric hindrence v1.1 probobly aocount for this behevior of the eorkes Alno-becarborg110 oold. Tho osters can be obtesnod from the cold chloride, whioh oan be preperod by heatIng the cosd with thsoryl entoride. The ootoro wero not earriod further bocause the Beaninoerridine hes

5 Pritzingos, J. I. pr. Ch. (2) 35, 200: 33, 582: 56, 285 6 . Boracho: Man., 57\%, 70-123 (2010) 
already beon doscribod In a patont of the Hoboto Easbruarizo?

It was thought tiant the banothyleminoeoriasno cotzld bo sormod thus:

$$
\text { ( }
$$

Exporinente Indseate that $\mathrm{Hz}$ has boen oplit ofs in tho eondensation of tho amino oxpound with Lodobone aone, but attongte to ioolate the rines product vere not eucceesfuh. The experiments cousd not bo roo pootod undor other condstions bocaune it took too wuoh timo to propero tho ensno compound.

Attempts wore aleo mode to roduce the oxime prepared from the eortdy eldohydo. These too wozo 
unsuccoseful under the condstsone usod.

Tho molting polnte givan in this thoese aso axy uncorrooted. They wero, however, mede with the some thornomotor undor 1dontloes condistons. 
Exporinontez

3(7)- Sthoryeor1asno,en

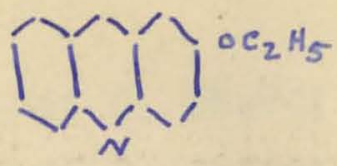

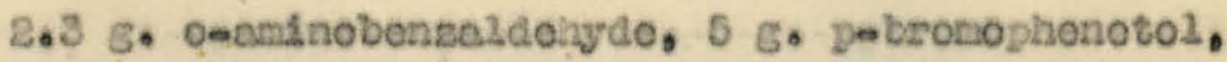
0.4 g. coppor ponder, 5 . enhyarous sodsus cerbonete. and 30 co. peltrobensono vero reflurod for 5 hours ot $280^{\circ}$. The excoes of the ghonetol and nitrobonaone wts zomoved by bteen asstillation. The rosiduo wao erstraoted with other, the other solutlon dr1od ovor sodivm sulfate, fliterod, end then evaporatod. The condensation produet wae dissolved in $15 \mathrm{ec}$ of Blaciel aootle sold and 3 eo. of cone. eukrurle oold woro edded. Mhde mixture wes then hestod on tho wator both for 5 minutes, joured into sue vater and

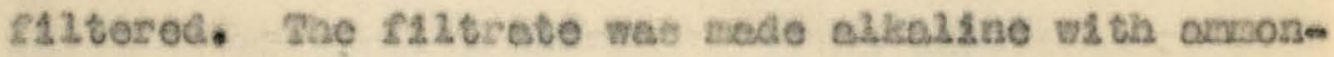
Lus hyroride. The proelp1 tete wee oryetellszod fron dilube aleohol. Jlekalng light yolkon pletes having a It: P. of $99^{\circ}$.

inal. Celod. $802 \mathrm{C}_{35} \mathrm{H}_{23034} \mathrm{C}, 80.60 ; \mathrm{H}, 5.07$ Joundt $\mathrm{C}, 30.51 ; \mathrm{B}, 6.22$ Plorate of $3(7)$-othoryeordalne, en The plorete wee

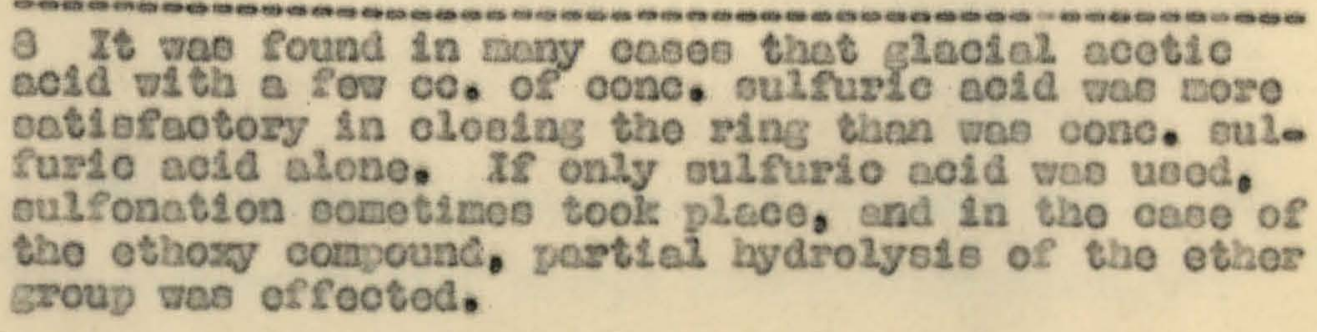


medo in elcoholio solution. It orystelstzed from acotono in stmo yolzow neodies. It did not molt at $250^{\circ}$.

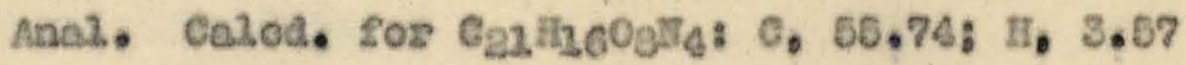
Iound: $\mathrm{C}, 50.07$ : 11.3 .03

flydrochlordeo, -20 the aleoholse solutson of tho othory compound, hydrochzorso actd was addod. Tho hudrochlorido salt proespateted out. It was crybtolo Issod from elcohol in bright yolkov noodkod. It dooomposed about $200^{\circ}$.

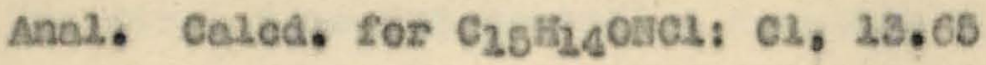
5ound: $\mathrm{c2}, 23.72$

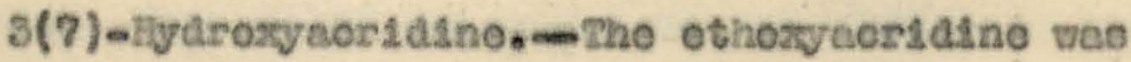
bollod for one hour wh th hudrlodse ac1d (bD. Gr. 2.7) and treoos of rod phosphorous. Thte wese dilutod vith water and mado elkaline vith sodiun hydrostde.

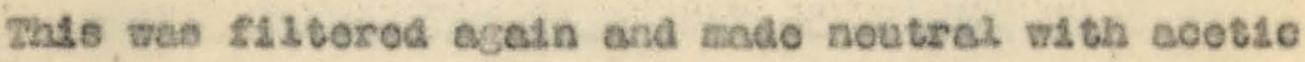
scid. The hudroxy ecridsno precipitetod outs It was oryotalissed from oleohol in youlow needlee. It asd not molt et $250^{\circ}$.

Anal. Calol. fos C33irgar: C, 79.27: H. 4.68 Dound: $\mathrm{c}, 79.83:$ I. 5.02 $1(0)$-lliothossyeor 1 dino.-<smiles>CC1CCCC2CC3CCCCC2CC1C3</smiles>

The condensetion was male in the sene way os the $3(7)$ oothoryecridsno ostcogt that o-bromoanleol woo tued In ploce of the pabromophenotol. The ortrece 
thon of tho condonsetion produot and rine elosuro wore done, elmiler2y. The mothory conpound wes rocrystele 14sed from 75\% alcohol. The 12 ght yolkon noedzoe no2t of $330-332^{\circ}$ 。

Anol. Celed. for C24th201: C, 00.35; $2,5.30$ Jound: $\mathrm{C}_{0}$. 80.25: $\mathrm{H}_{\mathrm{.}} 5.46$

zaozation of the condenestion produet of peansnobonseldohy do and cobromoons $83^{9},-$

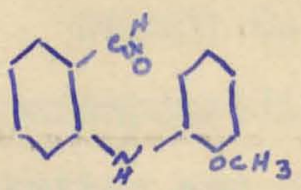

Tho firet tire tho preceding reection wes cerriod out, the condonestion product wes extrected with alo oukol. Wren water wos addod to the aleoholso solution somo oryotale wore somed elong whth an 013. Thooe oryetals wore zocryebalus sed from potroleum other as 18 ght yolkow orysteks, 13. P. 920.

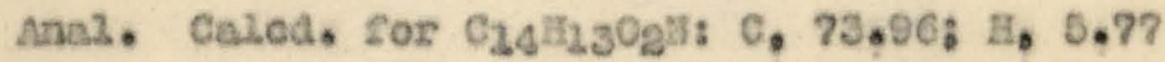
sound: $\mathrm{C}_{0}, 73.92 ; \mathrm{H}, 0.06$

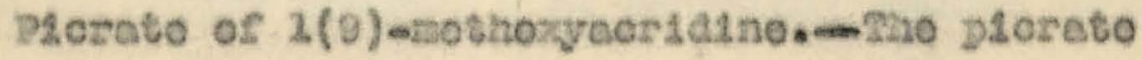
wes molo in alcoholic golution. It wo recryotalo

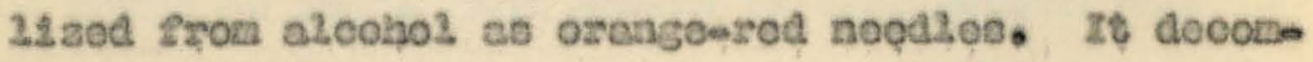
poeod about $250^{\circ}$.

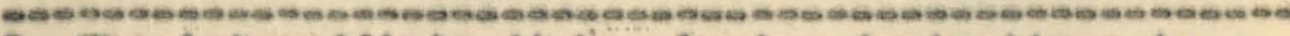
9 Tho intermdasoto diptieny lomino dorivatsvoo in theno sonctions are hard to ipolato bocunso at the high temporature ueod somo ring eloouse talree plece. Ior thas zoeson much time weo not opent in trying to isoloto thom. 


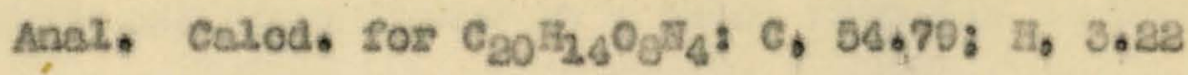
Eouncs $\mathrm{C}_{0}$.69.63: $\mathrm{H}, 3.28$

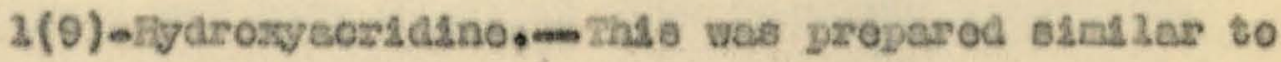
tho $5(7)$-hydrozyeortasno. It cryotelisacd from altuto

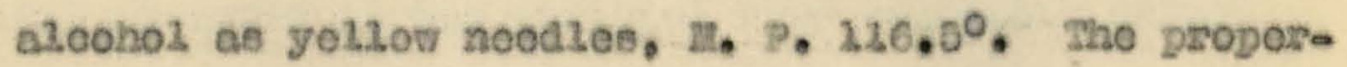
ties sare tho same as steted by llateumusa ${ }^{10}$.

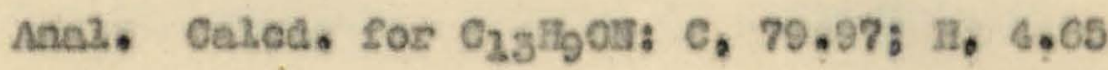
Dound: $C_{0} .00 .00: 5.4 .77$

Plerato of $1(9)$ - hy aroxysor1dino. $\rightarrow$ Who ptorato vae - modo in elcoholie solution and cryotallszod fron al- coliol eo rod noedtoo, 3r. P. 2360 20.

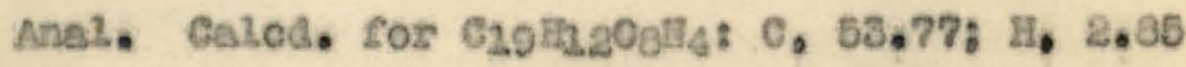
Sound: $\mathrm{C}, 53.628 \mathrm{H}, 3.36$

Sellothylecridiso.m<smiles>CC1CCCC2CCCCC2C1N</smiles>

3.5 B. Oenanoecotophonone, $7 \mathrm{~g}$. 20dobenaene, 0.4 G. coppor powder. 5 g. anhydrous eodlus cerbone ate, and 30 oo. of nstrobenzeno were restured for 4 houre at $220^{\circ}$. Tho ascees of sodobonsene and nftsobonzono wes ronoved by etean dietulation. Tho zooldre wes oxtrootod with other, this solution arlod ovor sodLum oulfato, Elztorod, and ovoporatod. Tho reniduo was alseolvod in $25 \mathrm{co}$ of gleoles cootic cold, 3 ce, or cone, sulfurto cold wero odded and the

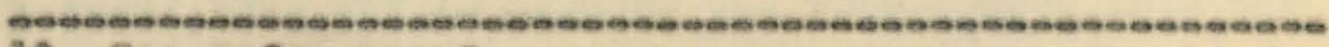
10 Boo rofosenco 2 
Eszture was thon hootod on a veter beth for 5 minuteo. It wos thon pourca into 200 water and s13torod. The flitrate wes rade alsalsno with enmonium hydrosido.

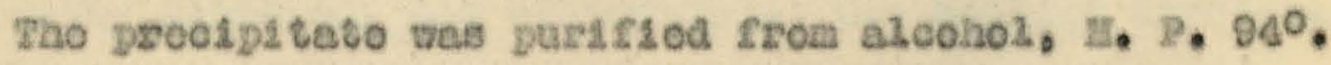
Jor anolyele $2 t$ was purigled from potroloum othor. 14. P. $126^{\circ}$. Tho properties agreo with the proportses of bernothyleorlasno properod by othor mothods. Anel. Colod. for $\mathrm{O}_{24} \mathrm{H}_{12} \mathrm{II} \mathrm{C}$, 07.01: $\mathrm{H}, 5.76$ Found: $C_{0} 07.33: \mathrm{Z}_{0}, 5.02$

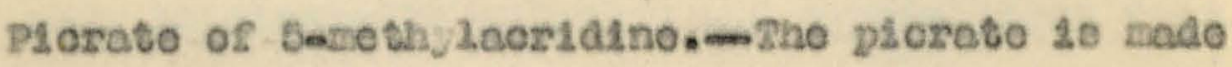

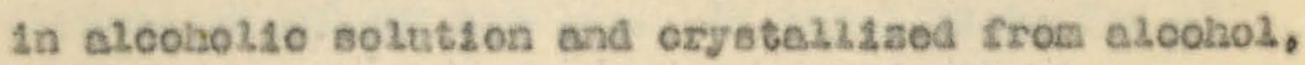
ㅍ. 2. $233284^{\circ}$.

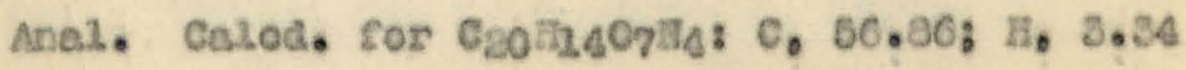
Eound: $\mathrm{c}_{0} 60.24 \mathrm{~b} \mathrm{H}, 3.03$

5. $3(7)$ - DLnothy Leorialne.-<smiles>CC1CCC2CCCCC2C1C</smiles>

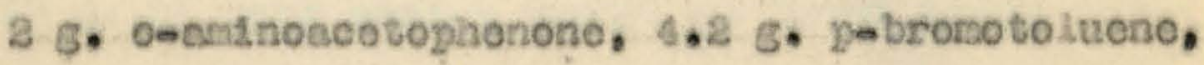
0.4 8. coppor powdor, 4 5. enhydroue sodum carbone

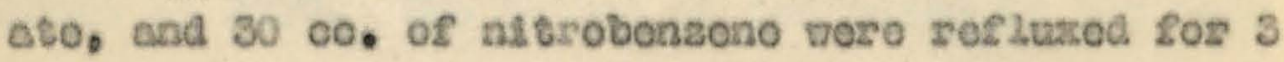
hours of $230^{\circ}$. The product was subjeoted to stoom distization and ortrected with other strilar to tho procodsng procodure. The 011 which zemotnod oftor evaporation of the other wes hested vith $35 \mathrm{ce}$ of conc, cootlo acld and $4 \mathrm{co}$ of cone. oulfurlo cold on a wetor bath for 15 minutos and thon pousod Into 1 co 
trotos. Fuse was fliterod and tho patrate wos mode

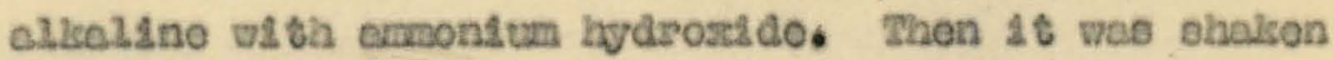
out with othor, the solution ariod over sodium oulo sato, flitorod, and ovaporatod. The reolduo erystale Inad from potroloun other se oroes colorod pletoe. II, P. $90^{\circ}$.

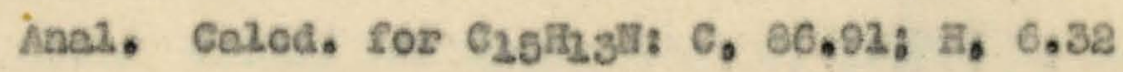
Eound: 0, 36.34: II, 6.52

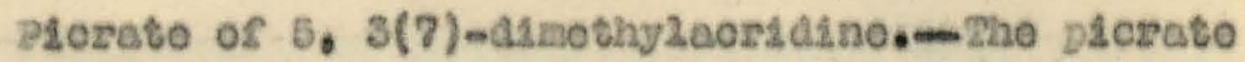
was modo in elcoholie solution and erybtallizod from eloohol ag yol tov noedzos. It began to derkon at $230^{\circ}$ and mostod at aaso.

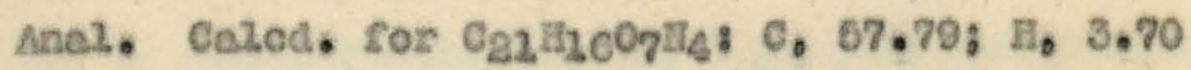
Found: $\mathrm{C}, 57.208 \mathrm{H}, 3.02$

Tho melting point of 5o $3(7)$-dsmothyleorddino is not $1 \mathrm{a}$ agreemont $\mathrm{w}$ thi the nelting point given by Donne ${ }^{32}$. Dos this soeson has experiment was ropostod.

25 Go of pure ecotyl phonyl pe toly2 emine vero heoted with 20 G. of enizydroue sine ohtoride for 10 hours at 3200 . Tho aethod of 1 soletsion is tho eano

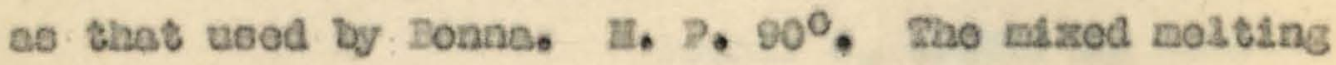
point sliswed no doproesion. The product of Donne asejat bo the 5, 2(0)-almothys corpound ${ }^{22}$. Thas bas 
tho 2h. 2. of $122-123^{\circ}$ wiatah 10 givon by Bonne for hie product.

Anek. Colod. for C25Hzit: C, 00.03: $\mathrm{H}, 6.38$

Bound: $\mathrm{C}_{\theta}$ 07.32: $\mathrm{H}_{0} 6.60$

The plorato hed tho same nokting polnt es tho produot proparod from omandnoecotophenono.

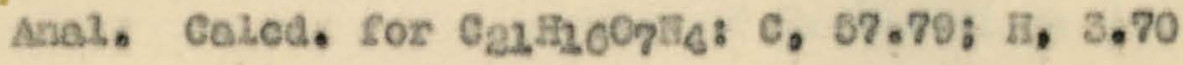

Found: C. 57.09: $11,6.07$

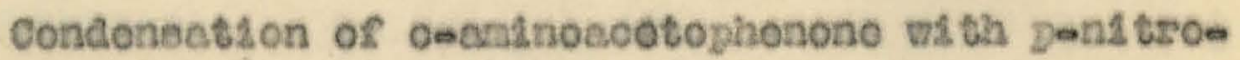
bromobonsono, -<smiles>CSC1CCCCC1NC1CCC(C)CC1</smiles>

3.4 G. O-andnoevotophenone, ? S. pent crobromobone

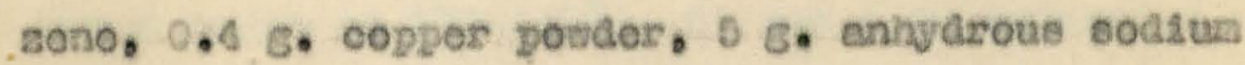
cearbonete, and 30 co. ndtrobenaeno woro rof2ussed for 3 houre at $280^{\circ}$. Artor stean esatskletion an 013 wee loft whioh solidiflod on cooking. Thle boldd wob oryotall1sed from elcohol. After bevoral rooryotelo 31sotions the yelzov neodses molted at $352^{\circ}$.

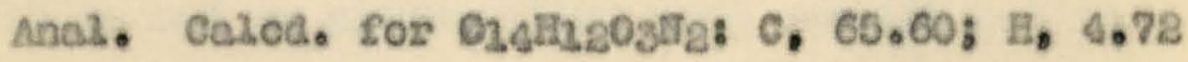
Dound: $e_{0}$ C5.52: $\mathrm{H}_{0} .5 .05$

$3(7)-711$ tro 5emothys aordasno.-<smiles>CC1CCC2CCCCC2CC(C)C1</smiles>

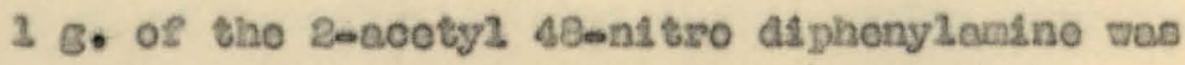
Assoolvod in $25 \mathrm{co}$ of cleotel scotio actd and thon

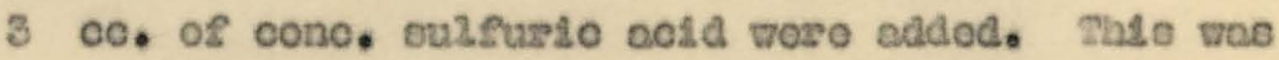


hootad on a vater both sor 10 minutoe, pourod 2 sto 100

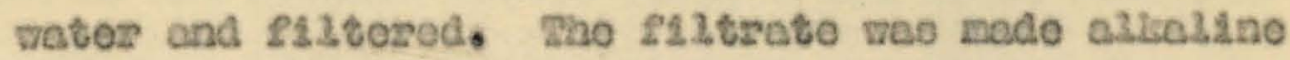
with omonium hydrostlo. The proolpttete wes gocryotale 21sod from aloohol as brownala youkow oryetelo whath asd not molt at $300^{\circ}$,

Anel. Calod. for C14thooglla: C, 70.57: 11 o 4.23 bound: $C_{0}, 70.65 \%$ H, 4.48

Condensetsion of bend tro Emchioro acetophonono with andino.n

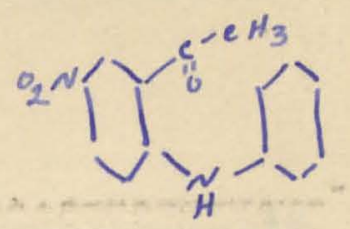

4 E. nitrochloroscetophonone 23 , 6. 5. potasalum cero bonato, and 5 oo. froshly discilied andilno wero boatod sor 5 hours of $370-200^{\circ}$. It was then extreotod with hot alcohol. Tho eryetale from this woro orystolls wod scon aleohol es 11 ghe youx ow needies, 4. P. $120^{\circ}$

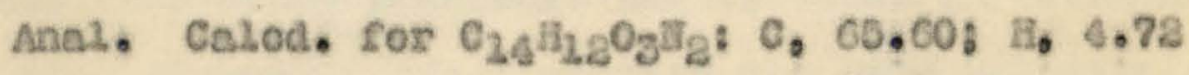

$$
\text { Found: } 6,05.60 \text { : }: 5.07
$$

The condensetsone of Dent tro Eechloro ecotoghenone

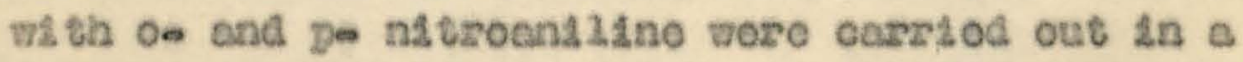
asmater way.

$3(7)$-lldtro Bemothy3 ecridsne.-

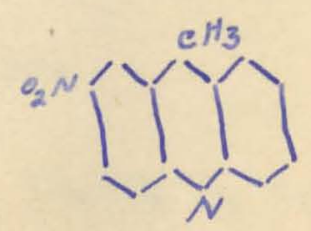

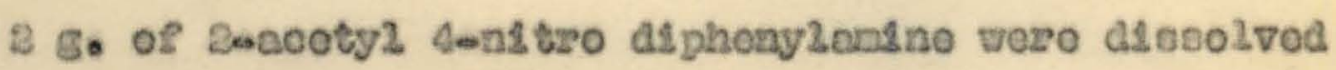


In 10 oo. eleolal cootso cold, $3 \mathrm{co}$, cono. busfurlo cold vero addod, and tho misturo wes hoetod for 20 Etnutos on a voter both. Tho mothod for puriglection Is tho sano ab for the othor compund. It did not nolt of $300^{\circ}$.

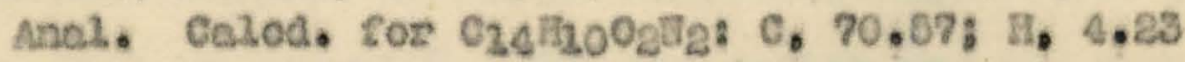
Found: $\mathrm{C}_{b} 70.40: \mathrm{B}, 4.53$

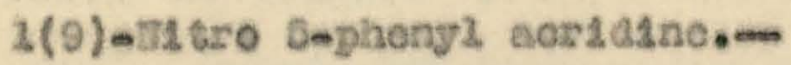

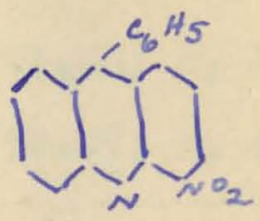

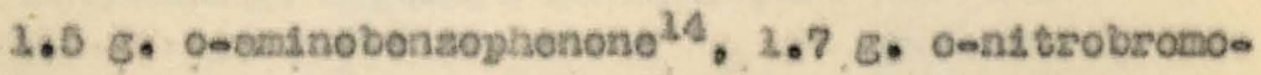
bonsono, $0.3 \mathrm{~g}$. coppor-powder, $3.0 \mathrm{~g}$. enhydrous oode Lum cerbonate, and $15 \mathrm{co}$ of ndtrobonsone voro rostursod

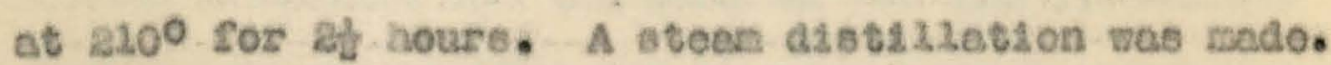
Astor cooling over alght the rosidue wos riltorod and Artod, Sho veuth procodure was followed in of feoting tho ring eloauro. Artor pouring tho cold solution into 100 vetor and meking eliseline with amonium hu droxldo,

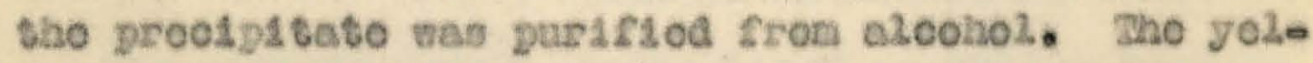

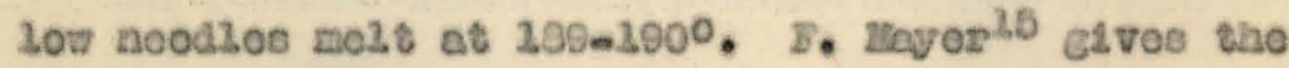

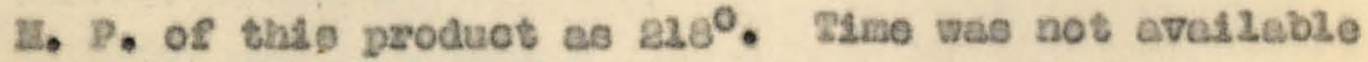
for zopeetsing the experimont of lleyos.

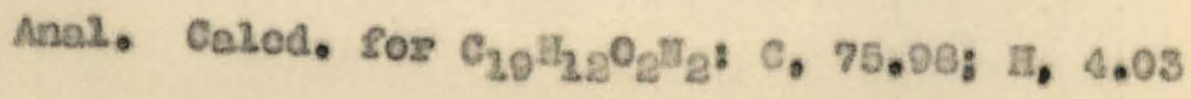
Pound: o, 75.92: H, 4.22 
3(7)-IItsco Sephongl somidino:-

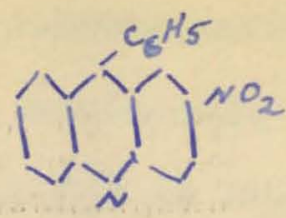

The procodure throughout wes tho same es thet gor the procodsng corpound, axcept thet pent trobromobonsene vas veod Instood of tho en compound. The yellow neede lce nole at $200-230^{\circ}$. Tho proportlos aro tho seno so Givon by D. mamenn ${ }^{36}$.

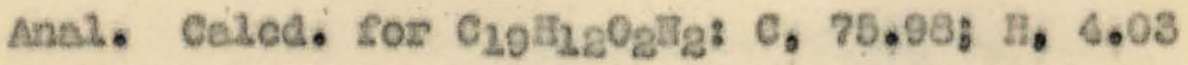
Found: $\mathrm{C}_{0}, 76.07 \mathrm{~F} \mathrm{II}_{0} \mathrm{4.20}$

3(7)-llothys Seghongl sortasne,-

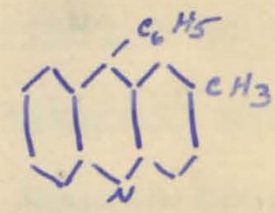

Tho proocdure wes the seve as for the $1(\theta)$ ent tro

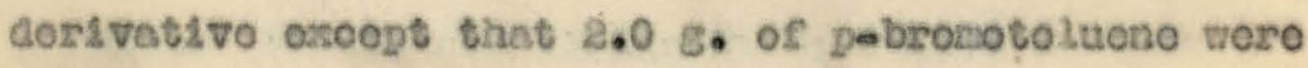
usod in pleco of tho oent trobromobenaene. Tho brom noddlos nolt at $130^{\circ} 7$.

Ano2. Calod. Sor C20Hzgli: C, 30.20: $\mathrm{H}_{0}$ 5.C2 Found: $C_{0}$ 09.27: $\mathrm{H}_{0}, 0.07$

The plorato thich oryeteliseod as yolkot noodsos meltod at $220^{\circ}$.

$3(7)$ - Bthory bephonyl sortasne.-

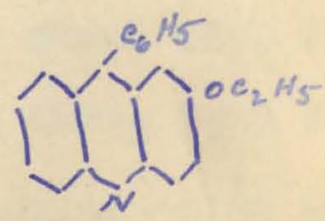

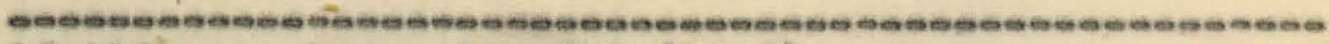
26 ulinans, Bos.. 30, 302 (2906)

27300 zororonco 33 
3.2 S. Ooentnobonsophonone, 4.0 G. jebromophonetol, 0.3 g. coppor pondor, 3.5 go sodsun oarbonate, and $25 \mathrm{co}$ of pltroborsono woro rofustod for at housb at $230^{\circ}$. Tho method of eatseotion, zing closuro, and proo clpltation wee similar to that of the othor compounde. It cryotalusod fron alcohol as gel.3ov plated, I. P. $105=307^{\circ}$.

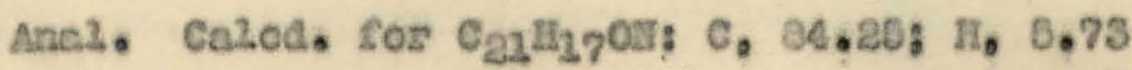
Bound: $\mathrm{C}_{0}$ Q $.10: \mathrm{H}, 0.90$

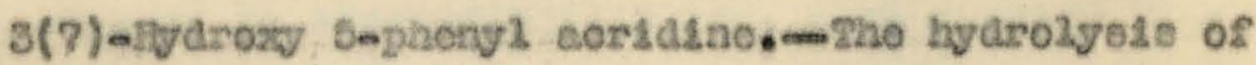
the othory conpound wos oerried out stmiler to thot of tho $3(7)$ eothoryecrtasno. It cryetolissed from allute alcohol in yolion lester. It booeno broma at $260^{\circ}$ and elntered without melting at $276^{\circ} 30$.

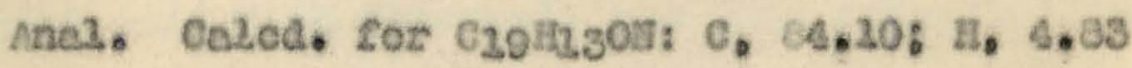
Iound: $\mathrm{C}_{0}$ S6.23: $\mathrm{H}_{6} 5.03$

Roduction of brono ondtro ecotophonono-jotesedun phenelintdo condonestion produet.-<smiles>NCCCCCN1C(=O)C2CCCC1CC2</smiles>

Ono grom of tho ghtholimsdo compound, viatola 1o

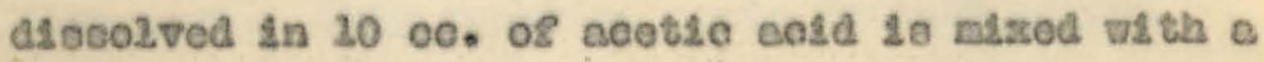
solution of 2.5 grone of crystellized snck 2 in $3 \mathrm{co}$ of sumsng BCL. Tho solutson gete a yolzor color and

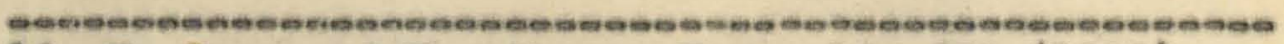
20 W. Hoss and Bosntheon. Bos.. 23, 005 (2005)

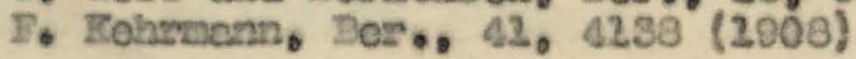




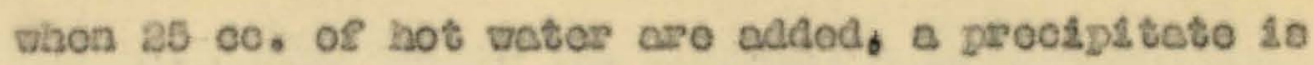
Eormod. H. P. $201^{\circ}$,

Condoneation of the ansno compound with Aodobongono.-

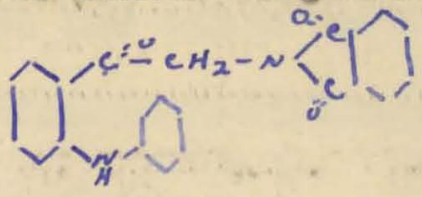

4 S. of the antno compound, 6.7 B. 2odobonzono, 0.3 8. copper powder, 3 S. anh arous sodum corbonoto. and $30 \mathrm{co}$. nstrobonzono wore rosutused for 4 hours at $220^{\circ}$. The orcose of 10 dobonsono and nitrobonsono

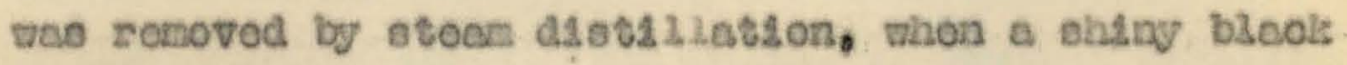
proc1piteto wes formod. This wees alseolvod in elcohol (asfloulthy - solublo). It was zooryotellsed from Eloohol, bolking with chercosh, the H. Po wes $392^{\circ}$. Somo of tho bleols proolystete wae oryetelusad from ecotio-cold with charcosh, and thon roorystalkisod

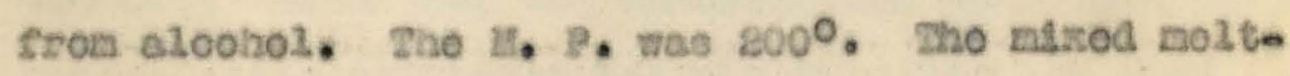
ing point with tho entine compound ohowod no doprossion, Indscesing thet thore was no roeotson. Baporibonte showed thowgh thes 113 had been formed in tho roegtion. A omald anount of a product having a 17 . P. of 20 S $^{\circ}$

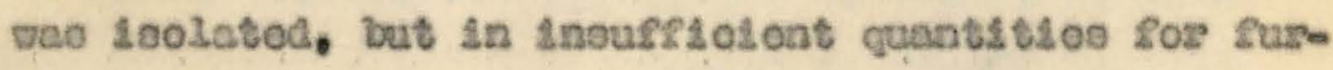
ther woslt. Whe reootion neode further obudy.

Carino of eosidys eldohyde.-

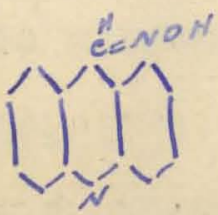

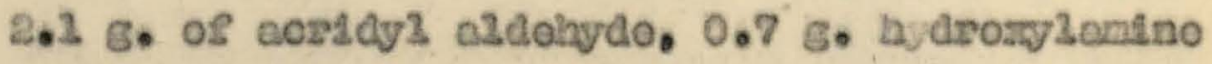
lavarochzorido and 0.7 E. sodiun othylate in aloobolsc

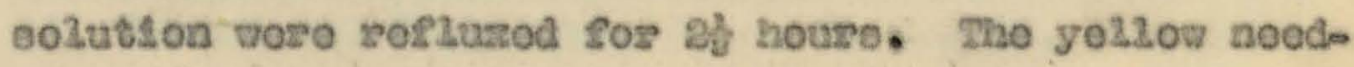


20 whtoh aro somod aro purssiod from mothyl alcos hol. $21.2 .247^{\circ}$,

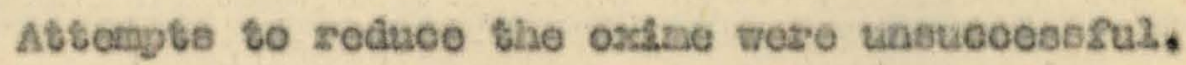

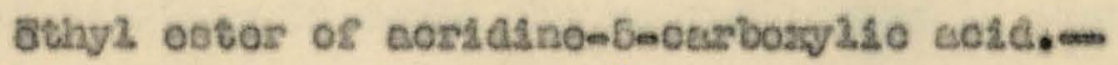

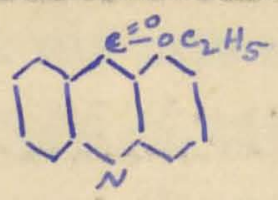

6.6 E. of acridincelecarbory 210 acte ${ }^{39}$ and $20 \mathrm{~B}$. of thiony 2 chloride voro roskusod for 2 houre in a rlasis vixled was conncoted to a rersur condonoor by 8 Ground gless jolnt, The exooss of thiongl chlorido ves romoved by ertreoting throe timoe with ebeoluto bonsene. Whos the residue vas askorod and woehod soverai times with bonzene. Tho seld chlorlde was Imoditetely rosturod whth $50 \mathrm{ee}$ or eboolute othys ateokol. Artor ol2 tho chlorldo hod gone into sole uthon, weter we edclod and the solutson wes modo

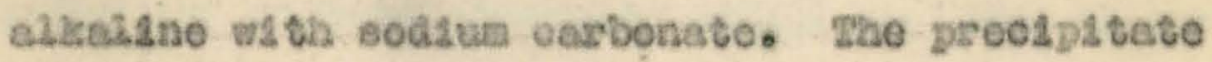
wos purifled from 4igrois. Tho ethyl eator proolpo 3totos out in yolkow mhombohedred platoe, th. P. 730 .

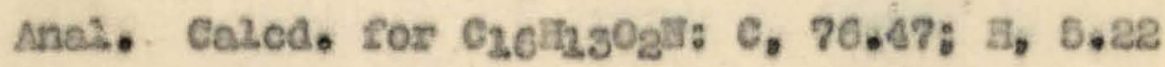
sound: $\mathrm{C}_{\mathrm{*}} 76.55$; $\mathrm{E}, 5.20$

Plosate of the othy2 eotor.-The plerate of the olhys estor ves mado in elcoholse eolution. Tho rhely yol2ow noedzoo molt of $2260^{\circ}$

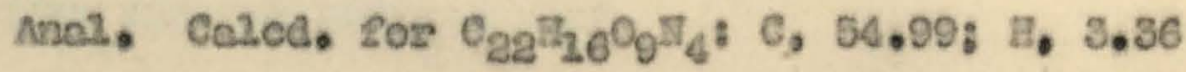
Jound: C, 55.23: $\mathbb{7}, 3.62$ 


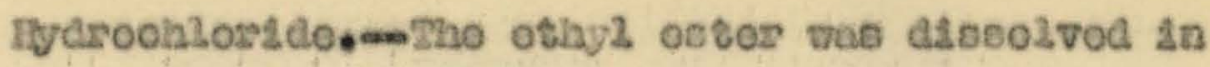

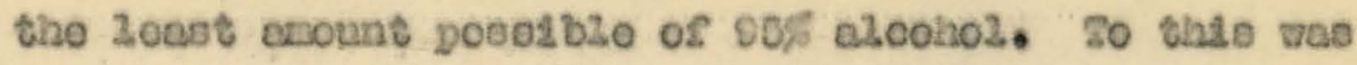
eddod conc. Hez. It wee nocesenry to edd ethos to

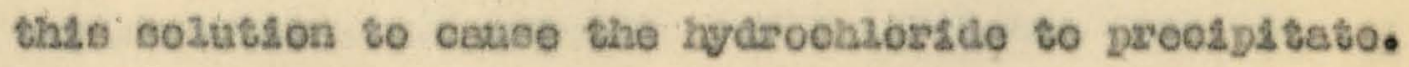
Tho yolzot noodzos did not molt at $250^{\circ}$.

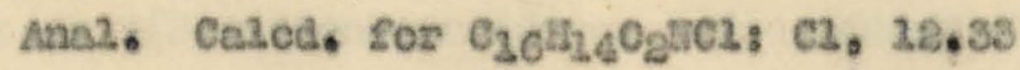

Jound: $\mathrm{CH}, 2 . \mathrm{e}$

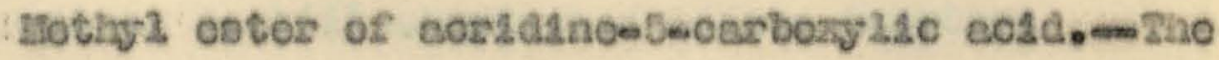
procothuro is the eane as thet for tho obhyz oetor ose

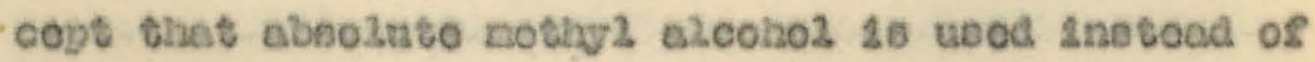
ebsoluto othyl eleohol. Tho mothy2 coter oryetelzsaod from nethy2 aloohol in elightzy yezlon needzoo. 2. $8.2 .26 .5-227.5^{\circ}$.

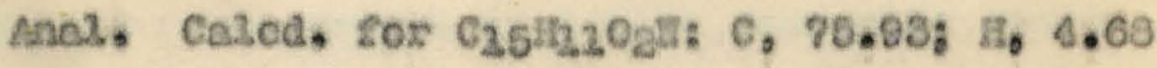
Jound: 6.70.28: $\mathrm{H}, 6.55$

Merbto of methy/2 estor.m. Tho pierato of tho mothy2 cotor wee rade in alcoholse eolut on. The yelzow noodzos molt et $289-230^{\circ}$.

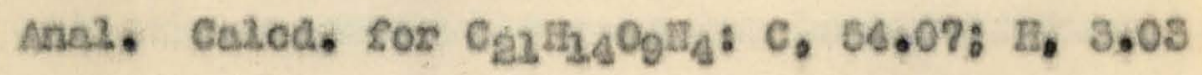
Iound: $C_{0}$ B6.35: 11.3 .02

Dycrochlorldo,-The mothod of propesatson of the hydreohloride anst of the mothy 2 oster was tho sone ae thet for the oth, 3 oeter, but tho use of othor wes not nocoosary for proolptetson. The yelzor noodzee esd not molt at $250^{\circ}$

Anal. Calod. SOR $\mathrm{C}_{25} \mathrm{H}_{22} \mathrm{O}_{2}$ ItTC2: $\mathrm{c2}, 28.06$ Sound: $\mathrm{Cl}, 28.89$ 


\section{Surwasy}

Tino mothod deecribod by Jonsen and Jztodrioh soz tho properatson of eorldine cestvatives hes beon oss tondod and tho solioving compounds have boen pro-

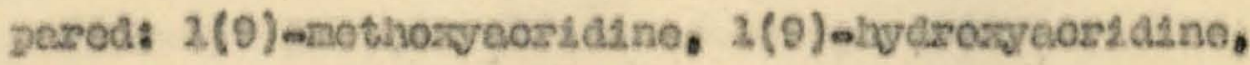
3(7)-othoryenstatno, 3(7) ahylroryacrdatno, belbothyle aoridino, 5, 3(7) anothyleordasne, Demothyz

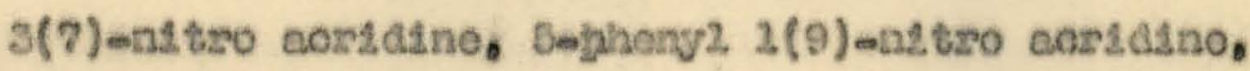
Soyhony2 $3(7)$-nttro contdsne, Demphony2 3(7) mothy2 corsdine, Dephony' 3(7)oothory acridine, and

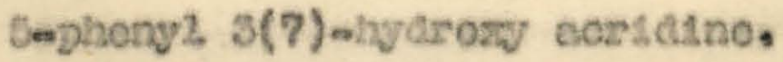

It has been shown thet the ohzorine in Canstro Sechloro sootoyhenone $4 \mathrm{~s}$ Lobize enough to react vith ansino and 2 ts ter 1 vout

Attompte to proparo tho eordainomilemethy leniso were tunouecosesys.

Tho propesctison of tho mothyl and othy 2 eaters

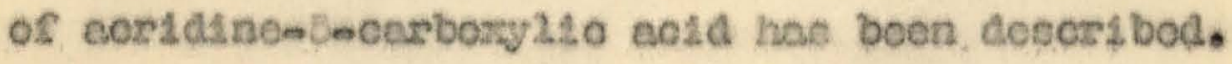

